\title{
Game Save The Sea! as an Education Media to Prevent Water Pollution
}

\author{
Alnando Harsono, Ridwan Sanjaya, Bernardinus Harnadi \\ Department of Information System, Faculty of Computer Science, \\ Soegijapranata Catholic University, Semarang, Indonesia \\ 13070009@student.unika.ac.id,ridwan@unika.ac.id,bharnadi@unika.ac.id
}

\begin{abstract}
Human's ignorance is the most threatening factor to natural water sources on the system. The habit of littering and poor waste management often occurs in developing countries, especially Indonesia. Through an educational game this message could be delivered easier.

This paper is intended to find ways for people to be more concerned with water pollution. The questionnaire and interview methods are used to search for pre-test and post-test data. From the pre-test data, "Save The Sea" mobile game is created which can help educate the public about the dangers of water pollution.

After 5 times playing of once each day, game testing was conducted to 39 people and fill the questionnaire. Post test data result shows that the game succeeded in creating conditions where people were more concerned about water pollution.

Keyword - Education, Game, Unity, Waste Management, Water Pollution
\end{abstract}

\section{INTRODUCTION}

Water is the main source of life[1] to all living creature in earth. Even though it is a renewable resources, clean water supply is still scarce because of the increasing growth of human population and water pollution.

Water pollution itself is a change of water's nature because of contamination of other substances. Sea water pollution will damage the natural habitat of flora and fauna[2] that live in the sea[3]. This change of balance will destroy the balance of sea ecosystem. The ocean have so many use in human's life, from regulating temperature, transportation, food, medicine, and many other things. Human is at a great risk of loss when sea's balance is disturbed.

Human produces many waste over the year. This waste production is often mismanaged, from littering through large scale industrial business. The growth of waste should be balanced with waste management[4], because sea will be the last place of waste. One of the most dangerous waste is plastic which in turn become microplastic[5][6] that is so small and take a long time to be degraded. To increase awareness of this matter, educational purpose that is more fun and engaging is needed.

History of games goes back from the ancient times of human life[7]. Game have been developed from its traditional form into the more advanced video game[8] form to meet society standard. As the form of game itself is developing, so the uses of it also develops[9].

Educational games is a modern way to teach people in more fun and sublime ways. Educational games does not lose its element[10] of fun, but will disguise its form of teaching, into more engaging way of approach to teach.

Smartphone or mobile phone is no stranger to human life nowadays[11]. One of its use is entertainment, where game was included in entertainment area. As of this matter, Indonesia[12] is one of those country that use mobile phone in their daily life. 
In the end, by using mobile game for educational media[13] to teach is needed to make people more aware of what is happening to a rising matter of water pollution.

\section{Research Questions}

Based on the background research, there are a few problems that could be formulated:

1. How to design games that can attract people to play water pollution education games?

2. What is the strategy so that the education message Save the Sea game! delivered to the player?

3. How to test the Save The Sea game! in conveying educational messages about water pollution to players?

\section{Research Objective}

Based on the Background Research, and the Formulation of the Problem, the objectives of this research are:

1. Make a game design that attracts interest for people to play water pollution education games.

2. Find a strategy to order the Save The Sea game! delivered to the player.

3. Know the impact of the educational message in the Save The Sea game! about water pollution in players.

\section{LITERATUR REVIEW}

\section{The Object of Data Collection}

In this research, the object of the data collection is the people in age of 11-55 years old that have phone to play games and currently living in Semarang that know about the matters of water pollution.

\section{The Technique of Data Collection}

Method of collecting data sources are qualitative[14]. During research, the data sources are divided into 2 different types; Primary Data, and Secondary Data. The Primary Data is obtained via online questionnaire where the type is quota sampling.
The Secondary Data[15] is obtained via online podcast video, E-Book, online Classes, online website, etc.

\section{Development Method}

During the development of the game there are steps, and preparation that are taken to create the educational game:

1. Gathering data about design, and learning the subject for the game.

2. Designing and collecting images to be used inside the game.

3. Further development of the game. This including creating all the coding that will be needed, and used in the playtest session.

4. Do game-testing session and spread questionnaire to the subject.

5. Analyze the Statistic Result, based from the collected questionnaire that has been given to the participant

6. Determined if the game fulfill all the standard requirement based on the statistic result.

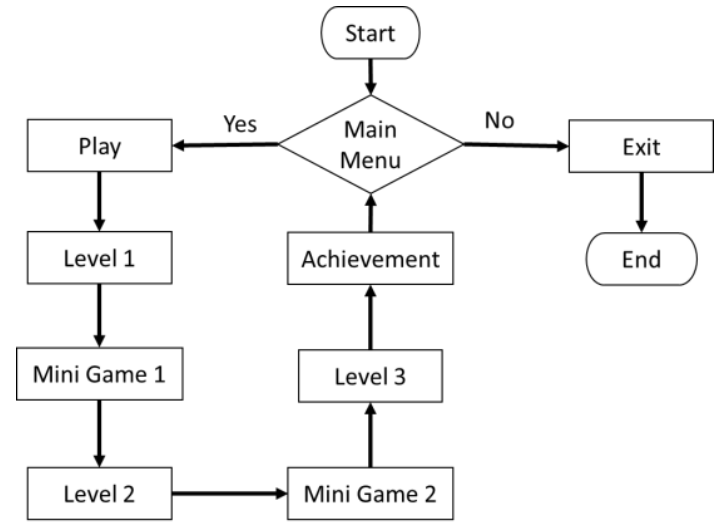

Figure 2.1 Game Development Flowchart

III. GAME DESIGN

The game design is started by picturing a story that will be told to the player as what usually human did and what is the after effect of the action of littering and bad waste management could do to the ecosystem of sea water. 


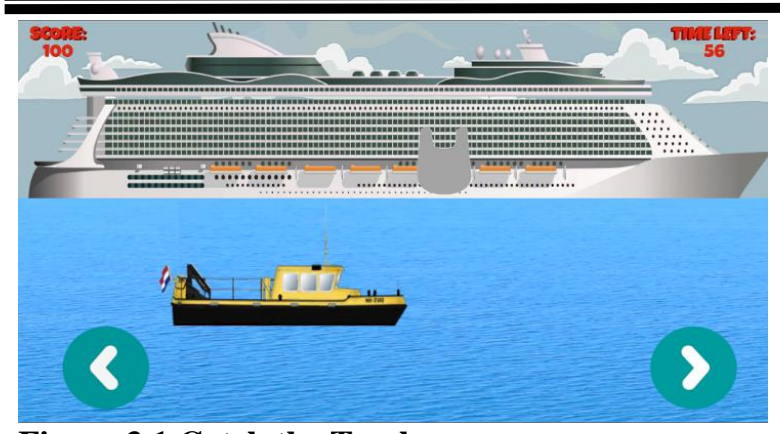

Figure 3.1 Catch the Trash

This stage is build based on the story of littering that human usually does. It is pictured by a big cruiser ship that throws garbage to the sea. We play as a patrol ship that keep the sea clean by catching those garbage that cruiser ship threw.

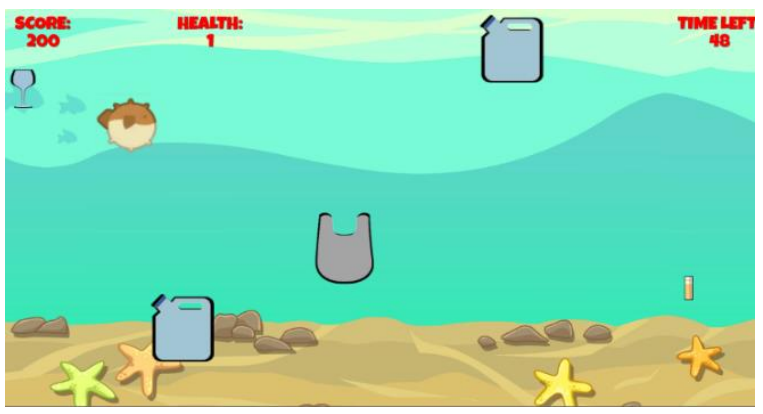

Figure 3.2 Fish Adventure

This stage is build based on the story of after effect of littering. We play as the fish that have to avoid the trash to stay alive.

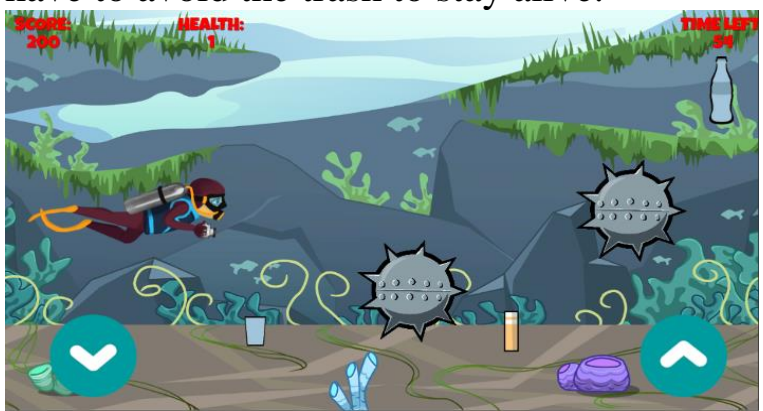

Figure 3.3 Clean the Sea

This stage is build based on the story of how hard human's effort to save the sea by cleaning trash. We play as the diver to clean the sea by picking up trash and avoiding sea mine (bomb). As the old saying," It is better to prevent than to cure".

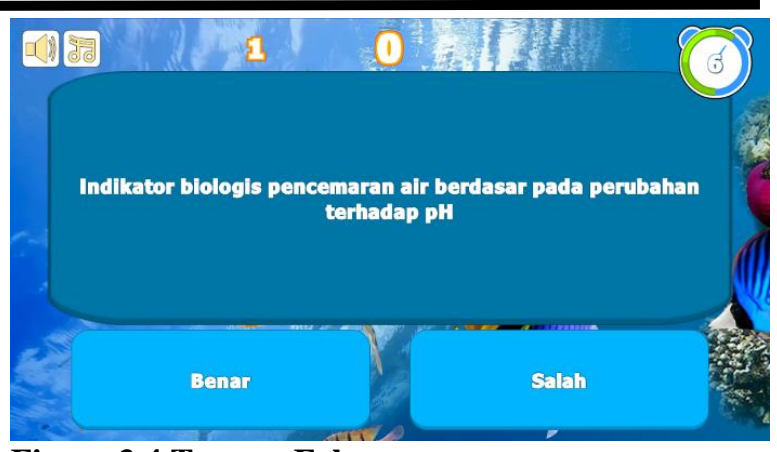

Figure 3.4 True or False

A game to check the fact whether it is true or false. To educate people about some fact about water pollution. This level will be used to determine how many lives the fish have.

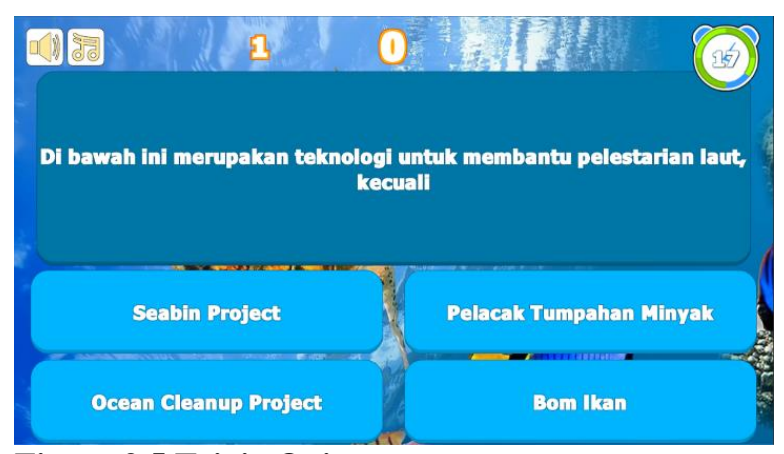

Figure 3.5 Trivia Quiz

Trivia game quiz, by choosing the right answer, we learn some facts about water pollution. This level will be used to determine how many lives the diver have.

\section{GAME EVALUATION}

Model and Hypothesis Development

H1 Enjoyment (E): Influence Intention to play Save The Sea! Game.

H2 Ease of Use (M): Influence Intention to play Save The Sea! Game

H3 Usefulness (B): Influence Intention to play Save The Sea! Game

H4 Attentiveness (P): Influence Intention to play Save The Sea! Game

\section{Description Analysis}

The process of gathering all of the data used in this statistic analysis was done by playing 5 times once each day by play testing, then handing out questionnaire to be filled by subject. The subjects are 39 people from Semarang City. The details can be seen in the table below. 1 of the data is removed in order 
to keep the validity of other data. Table 4.1 will show Demographic Description.

Table 4.1 Demographic Description Table

\begin{tabular}{|c|c|c|c|c|c|c|}
\hline \multicolumn{2}{|c|}{ Gender } & \multicolumn{3}{c|}{ Male } & \multicolumn{2}{c|}{ Female } \\
\cline { 2 - 7 } & \multicolumn{2}{c|}{18} & \multicolumn{2}{c|}{21} \\
\hline \multirow{2}{*}{ Age } & $0-17$ & \multicolumn{2}{c|}{$18-24$} & $25-31$ & \multicolumn{2}{c|}{$32-51$} \\
\cline { 2 - 7 } & 6 & \multicolumn{2}{|c|}{24} & 5 & \multicolumn{2}{|c|}{4} \\
\hline \multicolumn{2}{|c|}{ Education } & SD & SMP & SMA & D3 & S1 \\
\cline { 2 - 7 } & 1 & 4 & 18 & 1 & 15 \\
\hline
\end{tabular}

\section{Validity Test}

In this part the validity testing will help to determine which part of the survey that are valid for further statistic evaluation. In this case, the survey has 5 hypothesis that need to be tested by implementing 3 similar question for each hypothesis.

\section{Factor Analysis}

To ensure the validity of the result, a Factor Analysis is required in double checking the result of the Validity Test. By doing input of every variable into the SPSS we can check which variable did not match the requirement of being valid. Table 4.2 will show factor analysis table.

Table 4.2 Factor Analysis Table

\begin{tabular}{|c|c|c|c|}
\hline & $\mathbf{1}$ & $\mathbf{2}$ & $\mathbf{3}$ \\
\hline $\mathbf{E} 1$ & $\mathbf{. 8 7 0}$ & -.219 & .241 \\
\hline $\mathbf{E} 2$ &. $\mathbf{6 3 1}$ & -.188 & .414 \\
\hline $\mathbf{E 3}$ &. $\mathbf{7 0 1}$ & .059 & .476 \\
\hline M1 & .321 & .039 &. $\mathbf{7 1 0}$ \\
\hline M2 & .244 & .088 & $\mathbf{. 7 2 5}$ \\
\hline M3 & .083 & .116 & $\mathbf{. 8 6 9}$ \\
\hline B1 & .285 & $\mathbf{. 8 5 0}$ & .076 \\
\hline B2 & .067 & $\mathbf{. 8 5 8}$ & .084 \\
\hline B3 & .329 & .681 & .250 \\
\hline
\end{tabular}

\begin{tabular}{|c|c|c|c|}
\hline $\mathbf{P 1}$ & .214 & $\mathbf{. 5 7 7}$ & .401 \\
\hline $\mathbf{P 2}$ & .227 & $\mathbf{. 5 7 3}$ & -.001 \\
\hline $\mathbf{I 1}$ &. $\mathbf{7 7 8}$ & .363 & .236 \\
\hline $\mathbf{I} 2$ &. $\mathbf{5 1 9}$ & .658 & .054 \\
\hline $\mathbf{I 3}$ &. $\mathbf{7 3 1}$ & .316 & .246 \\
\hline
\end{tabular}

Based on the result of Table 4.2 we can conclude that Enjoyment (E1, E2, E3), Ease of Use (M1, M2, M3), Usefulness (B1, B2, B3), Attentiveness (P1, P2), Intention (I1, I2, I3) are convergent with their respective group, thus made them a valid variable.

\section{Reliability Evaluation}

After filtering the variable with Factor Analysis (Rotated). Now all of the variable will be tested for its reliability using Cronbach Alpha Coefficient.

Based on the reliability table, we can determine every variable that already been tested, and the result as on Table 4.3.

Table 4.3 Cronbach's Alpha Result Table

\begin{tabular}{|c|c|c|}
\hline Variables & $\begin{array}{c}\text { Cronbach } \\
\text { Alpha }\end{array}$ & $\begin{array}{c}\text { Internal } \\
\text { Consistency }\end{array}$ \\
\hline E & .863 & Good \\
\hline M & .754 & Acceptable \\
\hline B & .805 & Good \\
\hline P & .597 & Poor \\
\hline I & .857 & Good \\
\hline
\end{tabular}

As seen on the above table 4.3, the variable shown a various internal consistency. E, B, and I has a Good score, $\mathrm{M}$ has an Acceptable score, and $\mathrm{P}$ has a Poor score.

\section{Correlation Evaluation}

In the correlation test all of the demographic data, and mean variable (AE, $\mathrm{AM}, \mathrm{AB}, \mathrm{AP}, \mathrm{AI})$ are calculated to find the correlation between the variables.

Table 4.4 Correlation Table

\begin{tabular}{|c|c|c|c|c|c|c|c|c|}
\hline & $\mathrm{A}$ & $\mathrm{G}$ & $\mathrm{Edu}$ & $\mathrm{AE}$ & $\mathrm{AM}$ & $\mathrm{AB}$ & $\mathrm{AP}$ & $\mathrm{AI}$ \\
\hline $\mathrm{A}$ & 1 & -.046 & .192 & -.179 & -.015 & -.192 & .024 & -.243 \\
\hline $\mathrm{G}$ & -.046 & 1 & -.187 & -.039 & .005 & .013 & .120 & -.005 \\
\hline $\mathrm{Edu}$ & .192 & -.187 & 1 & -.009 & -.233 & .098 & -.049 & -.069 \\
\hline $\mathrm{AE}$ & -.179 & -.039 & -.009 & 1 & $.578^{* *}$ & $.420^{* *}$ & $.498^{* *}$ & $.703^{* *}$ \\
\hline $\mathrm{AM}$ & -.015 & .005 & -.233 & $.578^{* *}$ & 1 & .304 & .309 & $.485^{* *}$ \\
\hline $\mathrm{AB}$ & -.192 & .013 & .098 & $.420^{* *}$ & .304 & 1 & $.605^{* *}$ & $.650^{* *}$ \\
\hline $\mathrm{AP}$ & .024 & .120 & -.049 & $.498^{* *}$ & .309 & $.605^{* *}$ & 1 & $.495^{\text {** }}$ \\
\hline $\mathrm{AI}$ & -.243 & -.005 & -.069 & $.703^{* *}$ & $.485^{* *}$ & $.650^{* *}$ & $.495^{\text {** }}$ & 1 \\
\hline
\end{tabular}


Based on the result of Table 4.4 it was determined that factor Intention to keep playing game Save The Sea (I) is correlated strongly with Enjoyment (E), Ease of Use (M), Usefulness (B) and Attentiveness (P). While Attentiveness $(\mathrm{P})$ is correlated strongly with enjoyment rate $(\mathrm{E})$, perception to the usefulness (B), and intention to play again (I).

\section{CONCLUSION}

After a series of research, playtesting, and surveying, the results are concluded into: "How to design games that can attract people to play water pollution education games?" based on the research, people are more attracted to the game that has good graphic, simple and easy gameplay, and learn new things while playing aspect.

"What is the strategy so that the education message Save the Sea game! delivered to the player?" based on research, the strategy is by designing the game to be more enjoyable, ease of use, usefulness, and attentive.

Third question from the research question is "How to test the Save The Sea game! in conveying educational messages about water pollution to players?" based on research, educational messages in the game correlate with enjoyment rate, perception to the game's usefulness, and intention to play again.

\section{Recommendation}

This research is still far from perfect, and has a lot of flaws in it. during the whole span of this research, there're some mistake, and drawbacks that are hampering the research process. This research could be done better by fixing some issues such as:

1. Observe the use of audio visual in "Save The Sea" game for intention to play.

2. Observe the use of leaderboard in "Save The Sea" game for togetherness in playing.

3 . Observe the use of adding more mode in "Save The Sea" game for player's Attentiveness.

\section{REFERENCES}

[1] D. Dudgeon et al., "Freshwater biodiversity: Importance, threats, status and conservation challenges," Biological Reviews of the Cambridge Philosophical Society. 2006.

[2] D. J. McCauley, M. L. Pinsky, S. R. Palumbi, J. A. Estes, F. H. Joyce, and R. R. Warner, "Marine defaunation: Animal loss in the global ocean," Science. 2015.

[3] C. L. J. Frid and B. A. Caswell, Marine pollution. 2017.

[4] Agus Riyadi, "Pengelolaan Sumber Daya Air Yang Terpadu dan Berkelanjutan | Jurnal Lingkungan Hidup," Bumi Lestari Langit Bebas Polusi, 2012. .

[5] M. A. Browne et al., "Accumulation of microplastic on shorelines woldwide: Sources and sinks," Environ. Sci. Technol., 2011.

[6] J. A. Ivar Do Sul and M. F. Costa, "The present and future of microplastic pollution in the marine environment," Environmental Pollution. 2014.

[7] B. M. Berger, R. Caillois, and M. Barash, "Man, Play, and Games," Am. Sociol. Rev., 2006.

[8] S. Egenfeldt-Nielsen, J. H. Smith, and S. P. Tosca, "Understanding video games: The essential introduction," Routledge, 2008.

[9] J. Novak, Game development essentials: an introduction, 3rd ed. Cengage Learning, 2011.

[10] C. Crawford, Chris Crawford on game design. New Riders, 2003.

[11] A. J. A. M. van Deursen, C. L. Bolle, S. M. Hegner, and P. A. M. Kommers, "Modeling habitual and addictive smartphone behavior," Comput. Human Behav., 2015.

[12] Statista, "Smartphone User Penetration in Indonesia," 2019. [Online]. Available:

https://www.statista.com/statistics/257 046/smartphone-user-penetration-inindonesia/. 
[13] D. W. P. A. P. N. E. W. Puspitarini, "GAME EDUKASI BERBASIS ANDROID SEBAGAI MEDIA PEMBELAJARAN UNTUK ANAK USIA DINI," J. Teknol. Inf. dan Komunikasi, 2014.

[14] P. D. Sugiyono, metode penelitian kuantitatif, kualitatif,dan R\&D. 2016.

[15] Supsiolani, "Jurnal Studi Perpustakaan dan Informasi, Vol.2, No.1, Juli 2006," vol. 2, no. 1, pp. 32-36, 2006. 